\title{
Legal Frameworks, Normative Action and Performance of Biosocial Projects in Informal Settlements in Nairobi County, Kenya
}

\author{
Njeri Simon Ngacha ${ }^{1}$, Christopher Mwangi Gakuu ${ }^{2}$, Kidombo Harriet Jepchumba ${ }^{3}$ \\ ${ }^{1} \mathrm{PhD}$ Candidate at the University of Nairobi, P.O. Box 13125-00200
} ${ }^{2}$ Professor, Director School of Open Distance and e-Learning, University of Nairobi, Department of Educational Studies, P.O. Box $92-$
00902 Kikuyu

${ }^{3}$ Professor, Deputy Director School of Continuing and Distance Education, University of Nairobi, Department of Educational Studies P.O. Box $92-00902$ Kikuyu

\begin{abstract}
This scholarly work studied Legal frameworks, normative action and performance of biosocial projects in informal settlements in Nairobi County, Kenya. The objective of this study was to determine the extent to which normative action mediates relationship between legal frameworks and performance of biosocial projects in informal settlements in Nairobi County, Kenya. The variable indicators were derived from normative action and Legal frameworks indicators as independent variables against performance of biosocial projects indicators as dependent variable of this scholarly work. The study was premised on biosocial theory for the two independent variables and theory of constraint for dependent variable. Pragmatism and mixed research approach were embraced in this study to examine normative action, legal frameworks and performance of biosocial projects while descriptive and correlational research designs were adopted. Self-administered structured questionnaires were used to collect quantitative data while interview guides were used to collect qualitative data after the research instruments were pilot tested for validity through content related method and reliability through test-retest criterion. A sample size of 183 individuals from 61 biosocial projects were selected from a target sample of 70 biosocial projects in Nairobi County through Gakuu, Kidombo and Keiyoro, 2016 sampling formula $\left(s=(z / e)^{2}\right)$. Quantitative data was computed from structured questionnaires administered to 61 staff members working in the selected biosocial projects and 61 beneficiaries from the biosocial projects besides qualitative in- depth interviews with 61 State and non-state actors through purposive sampling technique. For descriptive data the statistical tools of analysis that were usedwere arithmetic mean and the standard deviation while for inferential statistics tools of analysis Pearson's Product Moment Correlation (r) and Stepwise Regression $\left(R^{2}\right)$ were used, hypothesis was tested by use of F-tests. To avoid invalidation of statistical analysis tests of statistical assumptions were carried out before data analysis. From the data analysis the null hypothesis that stated the relationship between legal frameworks and performance of biosocial projects in informal settlements in Nairobi County is not mediated by normative action was rejected with $F=15.207, p$ $=0.000<0.05, r=0.382$ and adjusted $R^{2}=0.136$ in step one against step two where $F=20.334, p=0.000<0.05, r=0.596$, adjusted $R^{2}=$ 0.337 and concluded that with an $R^{2}$ increasing by $20.1 \%$ and $F$ statistics increasing too there is strong moderation of Normative action on Legal frameworks and performance of biosocial projects in informal settlement.
\end{abstract}

Keywords: Normative action, Legal frameworks, performance of biosocial projects, biosocial theory, theory of constraint

\section{Introduction}

The rights of people with disabilities in Kenya are recognized under the national people with disabilities act of 2003, and 2010Kenyan constitution. Key agencies involved with promoting disability rights include the Kenyanational human rights commission, which has the authority to investigate, report and enforce the convention on the rights of persons with disability, and the national council for Persons with disabilities which is charged with ensuring performance of the convention on the rights of persons with disability and other disability rights instruments. In 2014, the Kenyan Parliament began the process of amending the disability Act so as to align it with the convention on the rights of persons with disability which was ratified by Kenya in 2008 .

In 2013, Kenya embarked on a decentralized system of governance with a two tier governance system, one being the National Government and the second tier being the County government. Decentralization entails, devolving power, resources, and representation to the 47 county governments as enshrined in the Con.2010 (GoK, 2012). This process has proven beneficial to people with disabilities as individuals can now advocate for actions on the rights of people with disabilities locally rather than from the national government. However, according to NCIDP, (2014), disability laws continue to be effectively enforced, and funds allocated for accessibility and inclusion may be reallocated to other projects subject to corruption and ineptitude of project implementers.

According to convention on the rights of persons with disabilities shadow report, disabled people organizations works to advance disability rights and have taken an active role in government negotiations and policy review by building the capacity of advocates to use legal frameworks, and participation in the country's convention on the rights of persons with disability, (NCIDP, 2014). Although disabled people's organization are instituted throughout the country and are managed by people who have a craving for inclusion and justice, they are largely voluntary based and lack funding. According to Nairobi county integrated development plan 2014, intensifying the political representation of disabled citizens and building disabled

Volume 9 Issue 6, June 2020 


\section{International Journal of Science and Research (IJSR) \\ ISSN: 2319-7064}

ResearchGate Impact Factor (2018): 0.28 | SJIF (2019): 7.583

people's organization capacity to enforce rights remain key priorities of the biosocial projects.

The National Council for Persons with Disabilities was set up in December 2004 following the enactment of the persons with disabilities Act number 14 of 2003. The National Council for Persons with Disabilities, the official arm of the government on disability issues, is under the Ministry of Gender, children and social development.Person with disabilities Act is a semi-autonomous Government agency under the Ministry of gender, children and social development, its vision is to promote disability mainstreaming in national development. The main role of national council of persons with disabilities is mainly to coordinate services for persons with disabilities in Kenya. The National council for persons with disability philosophyis to achieve the goal anchored on the need for greater collaboration, partnership and synergy between government ministries, departments, agencies as well as with disability based organizations.

The Ministry of Gender, children and social development is the focal point for disability issues in Kenya. Among its many services, the Ministry is responsible for 12 rural rehabilitation centers throughout the country and Nairobi's Industrial rehabilitation center, which train persons with disabilities for jobs. The national rehabilitation committee of the department of social services also provides for vocational rehabilitation services. It is decentralized into 49 Subcounty rehabilitation centers. Activities undertaken by the centers are part of the national rehabilitation program, which was established to provide persons with disabilities with the opportunity to acquire employable skills.

The Ministry of Education provides for children with physical and mental disabilities to be placed in mainstream schools, other key players include, The Kenya Institute of Special Education, a government institution established in 1986, with the aim of meeting the educational needs of disabled children, youth and adults and the Kenya National Commission on Human Rights, established through an Act of parliament, monitors abuse of human rights in Kenya for people living with disabilities. At the international level there is International Labor Organization which was ratified in May 2001.The other one is the International labor organization Convention concerning vocational rehabilitation and employment of disabled persons 1983 Number 159 which was ratified on 27 March 1990 and United Nations Convention on the Rights of Persons with disabilities 2006 and Optional Protocol ratified on 19 May 2008. Kenya strives to implement the action plan established for the African Decade of Persons with Disabilities, extended to December 2019 as a way to create a strong impression on advocating for the rights of persons living with disabilities.

\subsection{Statement of the problem}

People living with disability well referred to biosocial community have been working out modalities on how to secure their space and adapt to the growing demands of their needs. An outstanding 650 million people are living in extreme poverty and have disability of which 200 million are children, about $16 \%$ of them live in fragile countries. According to UNDP (2017) report, globally three billion people are using dirty sources of energy for cooking and heating besides losing through corruption every year, US $\$ 1.26$ trillion, which can be used to improve living conditions. In the past decade, 700,000 plus people have been killed in climate-related disasters, there has been a $50 \%$ increase in carbon dioxide emissions since 1990, besides political representation where only $23.5 \%$ of the world's parliamentarians are women, gender issues on matters of representation continues to affect policy development, with such a minimal representation it's a clear indication that gender challenges will be there for quite some time.

The urban population explosion has changed the landscape of African cities and also outstretched the meagre financial resources at the disposal of city officials. Instead of bringing inclusive growth and major developments to African cities, urbanization has resulted in the proliferation of informal settlements, commonly known as slums, widening income inequalities and intensifying urban poverty, (UNDP, 2017). Despite the informal nature of such settlements, slums are increasingly becoming a major challenge for policymakers For instance, according to the United Nations Population Fund's 2007 report on the state of the world, 72 percent of urban residents in sub-saharan Africa live in slum-like conditions. The unintended consequences of rapid urbanization in the region have posed major intricate policy challenges in relation to scarce livelihood opportunities for the poor and exposure to destructive heath conditions and low access to electricity and other social services.

Projects serving people with disabilities in Kenya are faced by innumerable challenges and the most debilitating one is the task constraint. Task constrain in project performance is perceived to be a generic term used for factors that are affecting the start and finish date of an activity. Generally, constraints in project apply for things like the scope, budget, and schedule of the project while task constraints, on the other hand, are restrictions that are imposed on tasks to start or finish on a certain date (Nyonje et al; 2012).Generally there are three types of constraints according to Project Management Institute; the first is soft constraints, second one is hard constraints and the third one is the constraints that offer a certain degree of flexibility. Within Nairobi County and its growing informal settlements people with disabilities have adapted on how to survive on such pressing environment without well-established physical infrastructure. The same applies to the biosocial projects as they operate within such tight situation coupled by complacency due to their varying types of disabilities. The distribution of the biosocial community in Nairobi county is as shown in table 1.1 below:

Table 1.1: Distribution of Population by disability

\begin{tabular}{|c|c|c|}
\hline Type of Disability & County \% & National \% \\
\hline Blind & 0.358 & 0.249 \\
\hline Deaf & 0.089 & 0.141 \\
\hline Dumb & 0.045 & 0.122 \\
\hline Physical & 0.222 & 0.311 \\
\hline Mental & 0.016 & 0.102 \\
\hline Other & 0.021 & 0.075 \\
\hline
\end{tabular}

Source, Nairobi County Integrated Development plan, 2014

Volume 9 Issue 6, June 2020 www.ijsr.net 


\subsection{Objective of the Study}

To determine the extent to which normative action mediates relationship between legal frameworks and performance of biosocial projects in informal settlements in Nairobi County, Kenya.

\subsection{Hypothesis of the Study}

$\mathbf{H}_{\mathbf{a}}$ : The relationship between legal frameworks and performance of biosocial projects in informal settlements in Nairobi County is mediated by normative action.

$\mathbf{H}_{\mathbf{0}}$ : The relationship between legal frameworks and performance of biosocial projects in informal settlements in Nairobi County is not mediated by normative action.

\section{Literature Review}

Nairobi County being the capital and economic hub for Kenya and its landlocked neighbours continues to grow at an exponential rate. Nairobi County has 65 biosocial projects working for People living with disabilities, (NCPWD, 2009); with such projects in place, it has been easy to push for enactment of legislations to support people living with disabilities. In 2003 an Act of Parliament aimed at providing rights and rehabilitation of persons with disabilities to achieve equalisation of opportunities for persons with disabilities was established. The Act was supposed to support setting up a council for persons with disabilities, the council was known as the national council for persons with disabilities. The core intention of the council was to hook up people living with disabilities with various institutions and opportunities in order to support their wellbeing. National council for persons with disabilities is a state agency corporation, mandated to articulate and instigate policies that are geared towards mainstreaming persons with disabilities into the conventional economy. It also seeks out to create an endowing environment in which persons with disabilities operate effectively and efficiently.

National Council for Persons with disabilities Act 2003 has six priority areas that guides its focus, the six priorities are; National development fund for persons with disabilities, the applications to the National development fund for persons with disabilities is open throughout the year.CashProgram that targets persons with severe disabilities who need permanent care including feeding, toiletry, and protection from danger by other persons, full time support has to be offered by a caregiver to ensure their needs are attended to. On the same breath the Albinism support program gives attention on implementing the National persons with albinism sunscreen support programme that give back care of sunscreen lotions to over 3,026 persons with albinism. The other priority area is the disability mainstreaming sector which focuses on facilitating disability mainstreaming programmes in public and private sector. On the same vein the job placement unit deals with analysing market information trends in order to disseminate market intelligence to the people with disabilities and finally the legal service department is the last key priority area that addresses in-house service provision within the Council.
The national development fund for persons with disabilities vouches for the provision of assistive devices and services to persons with disabilities in Kenya to enable these individuals function well in society. The fund gives priority to those individuals requiring assistance to function in a learning, training or work environment. The fund also provides grants to community and self-help groups for economic empowerment or revolving fund schemes. On the same breath national development fund for persons with disabilities provides backing to persons living with disabilities commencing from Primary, Secondary, Colleges and Vocational teaching institutions up to the University level. The aim of infrastructure and equipment grants is to enable the maintenance and growth of organizations which provide education or social services for persons with disabilities. Eligible organizations are education institutions, including special schools and special units, and social service delivery organizations, including non-government organizations and social care institutions.

To gain self-sufficiency, National development fund point towards helping persons with disabilities in generating income and to enable them to gain the skills and experience to access the loans required to grow their business. But, according to NCPWD (2012), the groups must primarily target persons with disabilities and this can be extended to the guardians of persons with disabilities. For biosocial groups to be eligible on accessing or receiving funding it must be at least one year old. Groups need to be legally registered to operate within the republic of Kenya and also registered with the national council for persons with disabilities in order to apply for that fund.Conversely, education assistance programme aims at improving persons with disabilities enrolment, retention and completion of education cycle for the eventual engagement in decent and gainful employment.

The Nairobi City County persons with disability Act 2015, provides for the rights and rehabilitation of persons with disability to achieve equalization of opportunities; to establish the county board for persons with disabilities and for linking purposes. The Act stipulates disability to include any physical, mental, sensory, psychological or other impairment, condition or illness that has or is perceived by significant sectors of the community, to have an extensive effect on an individual capacity to execute lifelong chores without strain. County Government Act 2012, stipulates that County governments mandate is to plan and make sure no public funds are utilized beyond a planning framework developed by the county executive committee and given consent by the assembly of the county.

Equally, County Government Act 2012, along with the public financial management Act 2012, calls for preparation of a county integrated development plans which must be aligned to the national development plan. In view of this, according to County integrated development plans and other plans provided in the county government Act they are aligned to the nation Vision 2030 and the medium term plans NCIDP (2014). As such county integrated development plans provides the essential linkages of the National and county governments by facilitating the performance of Vision 2030 leading projects to the same 


\section{International Journal of Science and Research (IJSR) \\ ISSN: 2319-7064}

ResearchGate Impact Factor (2018): 0.28 | SJIF (2019): 7.583

degree as additional projects and programmes that will ensure performance of Kenya Vision 2030 at both levels of government with a keen focus to biosocial projects.

From such point of view, vision 2030 performance is pegged on the medium term plans, it is thus imperative that county governments embrace the Kenya Vision 2030 and Medium Term Plans during preparation of county development plans. Of noteworthy, county governments are visualized to support performance of vision 2030 flagship projects that may be domiciled in or cut across the counties. In addition, counties are required to catch sight of specific projects and programmes for performance over the medium term period towards realization of the Kenya vision 2030 and sustainable development goals. According to NCIDP (2014), the county integrated development plan figures out the basis for county planning and development course of action by providing the indispensable benchmarks and information requisite for preparation of the county integrated development plans.

\subsection{Theoretical Framework}

The relationship between the theories and the variables normative action, legal frameworks and performance of biosocial projects in informal settlements is bound by theoretical framework. Devoid of theories knowledge, managers would be expending guess work, instincts, perceptions and hopes which may not be useful into the complex and dynamic organizations (Kidombo et al; (2013).Thus to avoid guess work or perceptions this body of knowledge theoretical framework represented two key variables of inquiry as enshrined under the objectives of the study in section 1.2 above. Theories that supported application of normative action, legal frameworks and performance of biosocial projects in informal settlements variables and standards to practical moral problems facing the biosocial community were the center of focus of thispublication. Below is the figure showing the relationship between the theory supporting predictive variable and dependent variable in this scholarly work.

\section{Biosocial Theory- $\left(\mathrm{X}_{1}+\mathrm{X}_{2}\right) \rightarrow$ Theory of Constraint - $(\mathrm{Y})$ \\ Figure 2.2: Theoretical Framework (Source Author)}

\subsubsection{Biosocial Theory}

In this study, biosocial theory supported normative action and legal frameworks as a mediating and independent variables respectively. According to Cloninger (1985), biosocial theory explains the shift from evolution to culture when it comes to gender and mate selection. Biosocial theory is a theory in behavioural cognitive processes and social science that illustrates disabilities, personality disorders and mental illnesses as biologically determined personality traits responding to environmental stimuli. Biosocial theory in motivational psychology identifies the differences between males and females concerning physical strength and reproductive capacity, and how these differences interact with expectations from society about social roles. This interaction produces the differences we see in gender.Thus biosocial theory is a collective expression for psychological theories that examine causes of psychological phenomena in biological factors and the social environment. Several of these theories lie close to the field of evolutionary psychology, asserting that their particular phenomenon has naturally evolved to fill a function in social behavior.

There are separate theories on personality, emotion elicitation and what effect emotions have on behavior and decision-making. A subset of biosocial theory is dedicated to the function and workings of emotion. Of particular interest is Linehan's biosocial theory of emotional dysregulation (Linehan, 2014). Though targeted at clinical therapy and psychological disorders, it makes some assumptions and claims that are interesting from an artificial intelligence perspective. Linehan's biosocial theory of emotional dysregulation describes emotional dysregulation as the inability to change or regulate emotional cues, actions, experiences, verbal responses and/or nonverbal expressions under normative conditions.

\subsubsection{Theory of Constraints}

The project success literature implies that projects have different characteristics and require different approaches. According to Ahlemann et al; (2012), projects are goal oriented undertakings thus project management primarily attempts to establish a process of achieving goals and thus the use of prescriptive theories is essential. Theory of constraints (TOC) began as a production scheduling aid, developed by Dr. Eliyahu Goldratt in the late 1970s, terming it as optimized production time table and it was quickly developed into a software package commonly known as optimized production technology.

Goldratt and Cox defined constraint as any element or factor that limits the system from doing more of what it was designed to accomplish or achieving its goal.Sebastiano \& Ragnhild (2014) revealed that what is considered as a constraint in project management can be categorized into four aspects; as political constraints such as defined vision, mission, scope of projects; technical constraints such as competencies, technologies, existing infrastructure and natural conditions like geology, landscape and climate, social constraints such as codes of conduct, organizational hierarchies, personal relationships and accepted or expected behaviors and administrative constraints such as budgets, project schedules, scope, written contractual agreements among others.

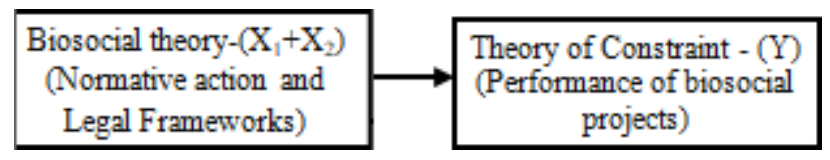

\subsection{Conceptual framework for the study}

A conceptual framework featuring in this scholarly work was used as the model of study to offer guidance on the variables correlation so as to make this publication remain engrossed and focused on the three key undermentioned variables as per the figure 2.2 below: 


\section{International Journal of Science and Research (IJSR) \\ ISSN: 2319-7064}

ResearchGate Impact Factor (2018): 0.28 | SJIF (2019): 7.583

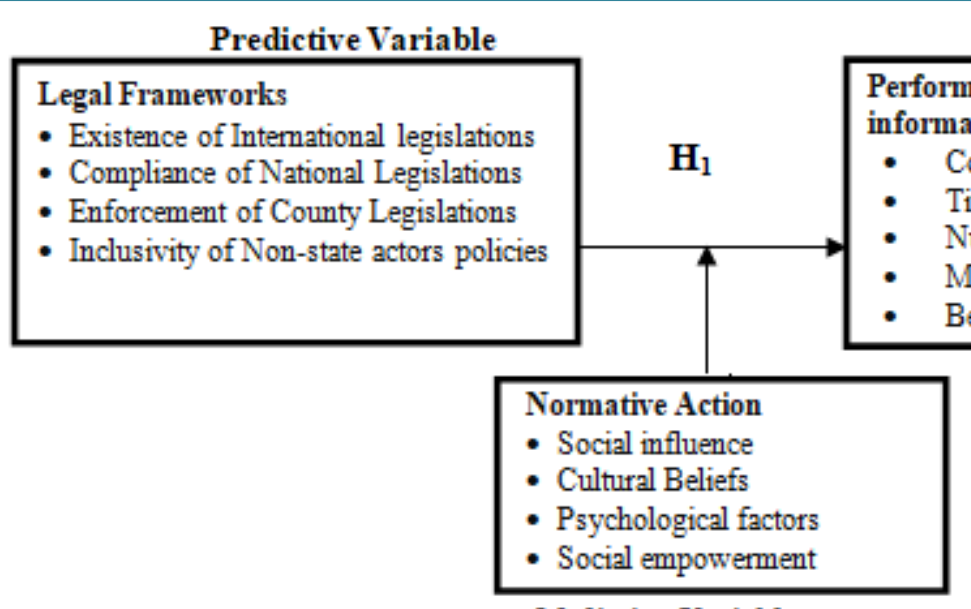

Response Variable

Mediating Variable

Figure 2.2: Conceptual Framework on Normative action, Legalframeworks and performance of biosocial projects in informal settlements in Nairobi County

\section{Research Methodology}

Research methodology authority in this study stipulated direction the investigation of the identified two variables. According to Industrial Research Institute (2010) which advances that research methodology helps the researcher to systematically find out all the possible answers of given research till logical conclusion of the study.

Conversely, this scholarly work will be informed by a postulated notion of Creswell (2012), who claims that paradigms are systems of beliefs that influence how researchers select both the questions they study and methods that they use to study them. Based on Gakuu et al; (2016), Creswell (2012) and Morgan (2007) philosophical reasoning, this study then was guided by pragmatism paradigm considering that it used mixed method of data collection and analysis since in addition pragmatism paradigm accommodates both the constructivist and positivist philosophies.

The research design for this body of knowledge was descriptive survey design and correlational research design. Research design refers to the overall strategy that integrates the different components of the study in a coherent and logical way, according to Gakuu et al; (2016) a descriptive study is one in which information is collected without changing the environment and can involve a onetime interaction with groups of people well known as cross sectional study or it might follow individuals over time well known as longitudinal study. According to Shield and Rangarjan (2013), descriptive survey is used to illustrate traits of a population or a phenomenon being examined. On the same breath, Creswell (2012) indicates that correlational research design is the measurement of two or more factors to ascertain the extent of relationship or change in an identifiable pattern.

The population target for this study were staff, beneficiaries and stakeholders working with projects targeting people living with disabilities in informal settlements in Nairobi County. According to Gakuu, Kidombo and Keiyoro (2016), population is the entire set of relevant units of analysis or data and it may be either finite or infinite besides being a group to which the results of the study are intended to apply. Estimation of population parameters according to Mugenda and Mugenda (2008) help in drawing generalization and thus the quality of this occurrence of research will not only stand or fall by the appropriateness of methodology and configuration but also by the suitability of the population sampling strategy that will be adopted. In this research three key respondents working in the same biosocial project were targeted, the three key respondents were: a key staff, a direct beneficiary living with disability and a stakeholder either state or non-state actor. The first two category of respondents were administered a questionnaire that collected the quantitative data and the latter who were the key informant was administered an interview guide which collected the qualitative data.

The selection of those three key members from each biosocial project targeting PLWD was informed by the understanding that is postulated by Gakuu et al; (2016) about the target population being a complete set of individual instances with some common characteristic to which the research wants to generalize the result of the study. Nairobi County has got a total of 65 Projects working for people with disabilities (NCPD, 2014), and thus out of those 61 projects were selected by use of Gakuu, Kidombo and Keiyoro sampling formular. Conferring to WHO (2003), $10 \%$ of a given population is expected to have one form of disability and therefore, Nairobi having a population of 4 , 475, 000 according to 2019 census means that the 65 projects targets $10 \%$ of that population which is 447,500 people living with disabilities of which part of the mentioned population in one way or the other is assumed to benefit from the biosocial projects or they may not and with such notions that's the sole reason a research was conducted to help unveil the true picture on the ground.

The sample size for the study was 183 respondents from 61 biosocial projects of which in every project 3 key respondents from each biosocial project was targeted thus making a total of 183 respondents for this study. The sample size was calculated using Gakuu et al;(2016) sampling formula $n=(\mathrm{z} / \mathrm{e}) 2$ 


\section{International Journal of Science and Research (IJSR) \\ ISSN: 2319-7064}

ResearchGate Impact Factor (2018): 0.28 | SJIF (2019): 7.583

$\mathrm{ME}=\mathrm{z}$

Where:

$\mathrm{ME}=$ the desired margin error

$\mathrm{n}=$ the sample size

$\mathrm{z}=\mathrm{is}$ the $\mathrm{z}$-score a number relating to the degree of confidence you wish to have in the result. $95 \%$ confidence is most frequently used and accepted.

The value of $\mathrm{z}$ confidence is 1.96 for $95 \%$ confidence.

$\mathrm{e}=$ the error you are prepared to accept, measured as a proportion of the standard deviation. In this study a margin error of 0.25 was accepted. According to Gakuu et al; (2016), a researcher can chose any margin error they like but need to specify it and thus in this body of knowledge a margin error of 0.25 was picked. In this case the degree of confidence adopted was 95\%.According to Gakuu, Kidombo and Keiyoro (2016); standard deviation will be based on the objectives set by the study being conducted.

Quantitative data was obtained using questionnaires while qualitative data was obtained by administering interview guides to 61 key informants who in this study were the state actors and non-state actors working with non-governmental organizations within the context of this study. To assess the authenticity and consistent of measurement validity and reliability of research instruments was conducted respectively. Research tools were piloted at Mathare constituency being one of the constituencies with high number of population and also the area being close from the pointwhereresearch data cleaning and analysis was being executed. Data was analyzed by employing descriptive statistics and inferential statistics whereby hypotheses were tested at the level of significance set at 0.05 and the confidence interval at $95 \%$.Correlation analysis was used to establish the relationship between predictive variables normative action and legal frameworks in addition to response variable performance of biosocial projects in informal settlement schemes.

\subsection{Tests of Hypotheses}

For empirical conclusions to be arrived at, a test of hypothesis was conducted. Table 3.1 indicates the summary of the research objective, research hypothesis, type of analysis and the interpretation of the results.

Table 3.1: Statistical Tests of Hypotheses

\begin{tabular}{|c|c|c|c|c|}
\hline Objective & Hypothesis & Model & $\begin{array}{c}\text { Level of } \\
\text { Acceptance/Rejection }\end{array}$ \\
\hline $\begin{array}{c}\text { To determine the extent } \\
\text { normative action mediates on the Analysis } \\
\text { relationship between legal } \\
\text { frameworks and performance of } \\
\text { biosocial projects in informal } \\
\text { settlements }\end{array}$ & $\begin{array}{c}\text { Ha.1: The relationship between } \\
\text { legal frameworks and } \\
\text { performance of biosocial projects } \\
\text { in informal settlements is } \\
\text { mediated by normative action }\end{array}$ & $\begin{array}{c}\text { Simple Linear } \\
\text { Regression and } \\
\text { Multiple Regression }\end{array}$ & $\mathrm{Y}=\beta_{0}+\beta_{1} \mathrm{X}_{1}+\beta_{2} \mathrm{X}_{2}+\varepsilon$ & $\begin{array}{c}\text { Reject } \mathrm{H}_{0} \text { if } \mathrm{p}>0.05 \\
\text { Fail to reject } \mathrm{H}_{0} \text { if } \mathrm{P}<0.05 \\
\text { Strength for relationship } \\
\text { for } \mathrm{r} \text { values will be } \\
-1 \leq \mathrm{r} \geq+1\end{array}$ \\
\hline
\end{tabular}

For the strength of the relationships, $r$ values were considered whereby:

$+0.10<\mathrm{r}<+0.29$; weak correlation;

$+0.30<\mathrm{r}<+0.49$; moderate correlation;

$+0.5<\mathrm{r}<+1.0$; strong correlation.

In stepwise regression modelling, if the considered variable was omitted from the final regression model, $\mathrm{HO}$ was accepted. Where $\mathrm{HO}$ was rejected $\mathrm{R} 2$ values were considered in determination of the strength of the relationship.

\section{Findings and Discussions}

Analysis, presentation, interpretation and discussion of the relationships of the objective of this body of knowledge which focused on establishing the extent to which normative action mediates relationship between legal frameworks and performance of biosocial projects in informal settlements in Nairobi County, Kenya was conducted. Subsequently, descriptive research design and correlational research design under mixed mode research approach were used in this study, descriptive, inferential and qualitative statistical analysis were carried out simultaneously in a cross-sectional manner. From the research objective, descriptive analysis was first done by testing mean and the standard deviation followed by inferential analysis through use of Person's Product Moment Correlation analysis to test the relationships of the variables of this body of knowledge. Since qualitative data was collected through interview guides, qualitative analysis was done after the descriptive and inferential statistics.

\subsection{Background information of the respondents}

Questionnaires that were administered to the respondents were 122 in total and out of that 117 came out completely filled while 5 were incomplete in some instances; this represented a response rate of $95.9 \%$ which was good for the study in terms of inferences. Conversely, Saunders et al; (2003) indicate that 30 to 50 percent response rate is reasonable enough for statistical generalizations and thus with the response rate of $95.9 \%$ in this body of knowledge it is thus satisfactory to deduce lessons from the analysis. Gender of the respondents is as shown in Table 4.1

Table 4.1: Gender of the respondents

\begin{tabular}{|c|c|c|}
\hline Gender & Frequency & Percentages (\%) \\
\hline Male & 32 & 27.4 \\
\hline Female & 85 & 72.6 \\
\hline Total & 117 & 100.0 \\
\hline
\end{tabular}

Results in Table 4.1 show that $85(72.6 \%)$ of the respondents who participated in the study were female while $32(27.4 \%)$ were male. The gender distribution was favorably skewed in respect to gender spread and thus it enhanced the quality of the analysis of results informed by the fact that this study was guided by pragmatism research paradigm which Gakuu et al; (2016) indicates as the best suited paradigm for mixed 


\section{International Journal of Science and Research (IJSR) \\ ISSN: 2319-7064}

ResearchGate Impact Factor (2018): 0.28 | SJIF (2019): 7.583

method research design in that it assimilates multiple realities in research like the gender factor.

\subsubsection{Distribution of respondents by Age}

The age group categorization was done to ascertain proper distribution. There were five categories, that ranged between 20 to 30 years, 30 to 40 years, 40 to 50 years, 50 to 60 years and the first category over 60 years. The distribution is depicted as per the table 4.2 below:

Table 4.2: Age of respondents

\begin{tabular}{|c|c|c|}
\hline Age & Frequency & Percentage \\
\hline $20-30$ & 18 & $15 \%$ \\
\hline $30-40$ & 33 & $27 \%$ \\
\hline $40-50$ & 22 & $18 \%$ \\
\hline $50-60$ & 5 & $4 \%$ \\
\hline Above 60 & 1 & $1 \%$ \\
\hline Age not reported & 43 & $35 \%$ \\
\hline Total & 122 & $100 \%$ \\
\hline
\end{tabular}

The glaring challengewas that many respondents could not freely indicate their ages as it is depicted on table 4.2 above. 43 out of 122 respondents did not state their ages, which exemplified by $35 \%$ of the entire sample. However, among individuals who reported, the largest age distribution was for those between 30 and 40 years at $27 \%$, then followed by persons who were between 40 and 50 years at $18 \%$, then those between 20 and 30 years at $15 \%$. The least in the category was age above 60 years which was at $1 \%$ an indication that this is an age category that is set at the verge of retiring for those working and for the beneficiaries then it can be deduced is the least reached in service provision.

\subsubsection{Test for statistical assumptions and analysis of Likert type of Data}

A number of prior tests were conducted to understand the suitability of the data used and similarly study the distribution and suitability of the data to make inferences. The tests conducted were: Test for normality, multicollinearity, singularity, homoscedasticity and heteroscedasticity. Further, discussion on how type I and type II errors were controlled and the suitability of using the Likert scale in the study were further realized.

\subsubsection{Normality test}

In order not to make biased or skewed conclusions it is ideal to check if the data being analyzed is normally distributed. The results of the inference tests would be skewed to one side in the event that the data is skewed on or either side. Regression analysis assumes that data has been collected from normal population of which negation of such normally lead to rejection of the data (Moriya 2008). Rather, the conclusion of the results of the sample may not be generalized to the whole population but could be just in favor of the sample studied. Kolmogorov-Smirnova (KStest) and Shapiro-wilk (SW-test) normality tests were simultaneously run in order to verify the distribution of the data.

Subsequently, under the Kolmogorov Shapiro-test statistic, we reject the null hypothesis if $\mathrm{p}<0.05$. While testing for normality, the null hypothesis in the study was that the sample population was not normal. In all the variables under investigation, $\mathrm{p}<0.05$ in which case we reject the null hypothesis and conclude that the samples were picked from a normal population. To countercheck the validity of the normality tests from KS-test statistic, Shapiro-Wilk tests (SW-test) were carried out. The $\mathrm{P}$ value in $\mathrm{SW}$-test is denoted as Sig. and it's the last column (Shapiro and Wilk, 1965). Kolmogorov-Smirnov test statistic (KS-test) establishes if two datasets vary significantly without making any assumption about the distribution of data.

In addition to calculating the D statistic, KS-test indicates whether the data is normal or lognormal. The test helps researchers to view the data graphically to understand how the data is distributed. The KS-test quantifies a distance between the empirical distribution function of the sample and the cumulative distribution function of the reference distribution, or between the empirical distribution functions of two samples (Corder and Foreman, 2009). Shapiro-Wilk (SW-test), tests the null hypothesis, to countercheck the validity of the normality tests from KS-test statistic.

When testing whether a population is normally distributed by use of SW-test, statistic, the null hypothesis is rejected if the value of W is too small (Shapiro and Wilk, 1965). In this study, all the SW-test statistics were approaching $1>0.05$ and hence the null hypothesis that the population was not normal was rejected. In conjunction with the $\mathrm{W}$ values, the p-values are also checked while using the SW-test statistic. In this case, if the p-value is more than the chosen alpha level, the null hypothesis is rejected and concluded that the set of data values are from a normally distributed population (Shapiro and Wilk, 1965). In this study, the alpha level was 0.05 and in all variables, $\mathrm{p}>0.05$ and hence it was concluded that the research population was normally distributed. The implication to this is that, the results of normative, legal frameworks can be a general picture of the population.

The interpretation of the tests in this body of knowledge observes from the hypotheses that:

Ho: Variable is not normally distributed

Ha: Variable is normally distributed

The results are depicted as per the table 4.3 below:

Table 4.3: Results for Kolmogorov-Smirnova and Shapirowilk Normality Tests

\begin{tabular}{|ll|c|c|c|c|c|c|}
\hline \multicolumn{9}{|c|}{ Tests of Normality } \\
\hline \multirow{2}{*}{ Statements } & \multicolumn{2}{|c|}{$\begin{array}{c}\text { Kolmogorov- } \\
\text { Smirnov }\end{array}$} & \multicolumn{3}{|c|}{ Shapiro-Wilk } \\
\cline { 2 - 8 } & Statistic & df & Sig. & Statistic & df & Sig. \\
\hline a) & Legal frameworks & .084 & 64 & .200 & .977 & 64 & .279 \\
\hline b) & Normative action & .104 & 64 & .080 & .949 & 64 & .010 \\
\hline c) & $\begin{array}{l}\text { Performance of } \\
\text { biosocial projects in } \\
\text { informal settlement } \\
\text { schemes }\end{array}$ & .105 & 64 & .075 & .977 & 64 & .290 \\
\hline
\end{tabular}

*. This is a lower bound of the true significance.

a. Lilliefors Significance Correction

\subsubsection{Multicollinearity and Singularity test}

In this study, multicollinearity was non-existent between the predictor variables. At some point in data analysis, singularity happens when an independent variable is formed from a combination of other independent variables. On the

Volume 9 Issue 6, June 2020 www.ijsr.net 


\section{International Journal of Science and Research (IJSR) \\ ISSN: 2319-7064}

ResearchGate Impact Factor (2018): 0.28 | SJIF (2019): 7.583

other hand, multicollinearity is checked by analyzing the tolerance values under collinearity to ensure that the assumption is not violated (Asteriou and Hall, 2011). For instance, 1 - R2 values should be more than 0.1 which implies low multicollinearity (Shirley et al., 2005). If two variables are perfectly collinear, singularity is said to exist and an exact linear relationship exists between the two predictor variables with a correlation coefficient equal to 1.0 or -1.0 .

The independent variables had a VIF of less than 10, and the mean VIF of 2.593 was less than 4 an indicator that the variables did not have a linear relationship among themselves, particularly there was no multicollinearity. In the event there is multicollinearity the results can have very large standard errors of the beta coefficients hence a higher variability across samples and hence a less chance to represent the population. Multicollinearity may also reduce the contribution of the independent variables making it difficult to assess the individual significance of the predictors.

The study adopted this approach and the results are as shown in Table 4.4 below:

Table 4.4: Variance Inflation Factor (VIF) Results

\begin{tabular}{|c|c|c|}
\hline \multirow{2}{*}{ Independent Variables } & \multicolumn{2}{|c|}{ Collinearity Statistics } \\
\cline { 2 - 3 } & Tolerance & VIF \\
\hline Legal frameworks & .387 & 2.586 \\
\hline Normative action & .385 & 2.600 \\
\hline Mean & & $\mathbf{2 . 5 9 3}$ \\
\hline
\end{tabular}

a. Dependent Variable: Performance of biosocial projects in the informal settlements in Nairobi County

\subsubsection{Tests for Heteroscedasticity and \\ Homoscedasticity-Levene's test}

Homoscedasticity is an assumption that the dependent variable has equal variance across the range of the independent variable; consequently, heteroscedasticity is the nonexistence of homoscedasticity. Homoscedasticity and heteroscedasticicity was counter checked by plotting scatter diagrams prior to undertaking correlation analysis. A sequence of random variables in statistics is homoscedastic if all random variables in the sequence have the same finite variance.

Heteroscedasticity in regression analysis can invalidate statistical tests of significance that assume that the modelling errors are uncorrelated and normally distributed and that their variances do not vary with the effects being modelled. A collection of random variables is heteroscedastic if there are sub-populations that have different variabilities from others. Hamsici and Aleix (2007) in SphericalHomoscedastic distributions, claim that the correlation and residual tables generated by SPSS that are used to test for collinearity can also be used to check for existence of heteroscedasticity. In this study, this assumption was not violated.

Table 4.5 below stipulates the test of homogeneity of variances
Table 4.5: Test of Homogeneity of Variances

\begin{tabular}{|c|c|c|c|c|}
\hline Independent Variables & Levene Statistic & df1 & df2 & P-value \\
\hline Legal frameworks & 2.193 & 23 & 54 & .099 \\
\hline Normative action & 2.916 & 23 & 50 & .101 \\
\hline
\end{tabular}

The factor in testing homogeneity is performance of projects, while the variable is legal framework. The p-value is more than 0.05 implies the variables have met the assumption of homogeneity of variance that states there is equal variance across the range of the study variables.

\subsubsection{Control of Type I and Type II Errors}

Rejection of a true hypothesis or fail to reject a false hypothesis may lead to committing either type I or type II error. According to Osbone and Waters (2001) removal of univariate and bivariate outliers may reduce the probability of committing either type I or type II errors and improve the accuracy of results. In cases of simple correlations and regressions, unreliable measurement may cause relationships to be under estimate thus increasing the risks of committing type II errors. For multiple regression or partial correlation, the effect of sizes of other variables may be over-estimated if the covariate is not reliably measured. In this analysis, a correction of low reliability was conducted and obtained a composite Cronbach alpha of 0.944 and this ensured obtaining a true picture of the relationship of the variables and thus minimizing the likelihood of overestimation during multiple regressions.

\subsubsection{Analysis of Likert Type Data}

In the study on equidistance of Likert-type scales and validation of inferential methods using experiments and simulations, Lantz (2013) indicates that Likert-type data are often assumed to be equidistant by applied researchers so that they can use parametric methods to analyse the data. Since the equidistance assumption is rarely tested, Lantz (2013) argues that the validity of parametric analyses of Likert-type data is often unclear and that the preferred statistical method to analyse Likert-type data depends on the nature of their non-equidistance as well as their skewness. Fraukeet al; (2008) argue that when a questionnaire is too lengthy, the response rate is low and the quality of the responses is compromised. In addition, Frauke et al. (2008) propose that ten objectively constructed items for each research variable in a Likert type scale are sufficient to measure a required construct where mathematical modelling is involved in data analysis thus necessitating the need for coalescing indicators of various variables.

The study had four main variables to test; the four variables had sub-variables which had statements on a Likert scale of 1 to 1 points. The scale ranged from 5=Strongly Agree (SA), 4 = Agree (AG), 3 = Neutral (NE), 2 = Disagree (DS), $1=$ Strongly Disagree (SD). The analysis of Likert scale is based on Carifio and Rocco (2007) who contends that the scale be; from 4.2 to 5.0 strongly agree, 3.4 to 4.1 be somewhat agree, 2.6 to 3.3 be neutral, 1.8 to 2.6 be somewhat disagree, and 1 to 1.7 be strongly disagree hence giving an equidistance of 0.8.In addition as recommended by Alan (2001) in the selfadministered questionnaire in this study, the questionnaire sections comprised of items in a Likert type scale format using a scale of SD - Strongly Disagree; D - Disagree; N Neutral; A - Agree; and SA - Strongly Agree.

Volume 9 Issue 6, June 2020 www.ijsr.net 


\section{International Journal of Science and Research (IJSR) \\ ISSN: 2319-7064}

ResearchGate Impact Factor (2018): 0.28 | SJIF (2019): 7.583

4.4 Overall Descriptive Analysis on Normative action, LegalFrameworks and Performance of biosocial projects in informal settlements

Normative action is one of the independent variable of this study. The variable was measured using six indicators namely: Social influence-conformity, social influenceobedience, social influence-compliance, psychological factors, cultural beliefs and social empowerment. On each of these indicators which could help respondents to rate their level of satisfaction on each element were derived. On each indicator, the respondents were required to rate the extent to which they agreed, were neutral or disagreed on each aspect as under mentioned then a composite mean and standard deviation was derived at the discussion level of as the closing facet of normative action.

Normative action was measured in terms of Social influence-conformity to social norms, Social influenceobedience to social norms, Social influence-compliance to social norms, Cultural Factors and Psychological factors. The mean, standard deviation and sample size who responded to each aspect and the standard deviation for each element are shown on Table 4.6:

Table 4.6: Mean and Standard Deviation of Normative action

\begin{tabular}{|c|c|c|c|}
\hline Normative action & $\mathrm{n}$ & $\begin{array}{c}\text { Mean } \\
(\mathrm{M})\end{array}$ & $\begin{array}{c}\text { Standard } \\
\text { Deviation }\end{array}$ \\
\hline Social influence-conformity to social norms & 102 & 3.22 & 1.26 \\
\hline Social influence-obedience to social norms & 103 & 3.33 & 1.22 \\
\hline Social influence-compliance to social norms & 101 & 3.023 & 1.32 \\
\hline Cultural Factors & 97 & 3.77 & 1.25 \\
\hline Psychological factors & 103 & 3.67 & 1.19 \\
\hline Social empowerment & 101 & 3.13 & 1.25 \\
\hline Composite mean & & $\mathbf{3 . 3 5 7}$ & \\
\hline
\end{tabular}

Among the factors, Cultural factors and psychological factors had the highest means which were closely equal to 4 an implication of agree, which shows on average the two items of normative action were observed to be important in explaining performance of biosocial projects in informal settlements. In terms of ranking of the other items, social influence-obedience to social norms was higher with a mean of 3.33, followed by social influence-conformity to social norms with a mean of 3.22 , then social empowerment with a mean of 3.13 and finally social influence-compliance to social norms with a mean of 3.023. The composite mean was 3.357 which was approximately 3 an indicator of neutral, showing that on average the respondents were neutral on the impact of normative action to performance of biosocial projects in informal settlements. Each variable was further analyzed to find out the distribution of the responses, the results were discussed in the preceding subsections.

Theoretical and literature review under this variable points that there is a reason to believe that failure to adapt norms in society causes prejudice, stereotype and stigma. Grandal et al; (2013) show that the factors that contribute to the prejudiced personality are mostly measures of the inability or unwillingness to adapt to social change that is cognitive rigidity, authoritarianism, low education and traditional religiousity. To overcome a negative attitude as an outcome of prejudice, Crandall et al; (2002) demonstrates the adaptation to social norms leads to the repression of prejudices besides different emotions leading to different types of action. Deliberating on Van Zomeren (2013), differing emotions are determined by a more basic characteristic about whether groups and the world in general can change. Van Zomeren et al; (2011) proposes on collective action profound impact in the modern world, the question of how people engage in collective action as the subject of growing social psychological research.

Subsequently the other independent variable was legal frameworks. Legal framework was to explain performance of biosocial projects in informal settlements mediated by normative action. Legal framework was measured in terms of four indicators, namely: existence of international laws, compliance of national legislations, enforcement of county legislations and inclusivity of Non-state actor's legislations. Each Legal framework indicator was extensively analyzed in terms of distribution of the responses; the responses were discussed in the literature review by triangulating the theoretical study under the legal frameworks and its relevance in the contemporary study and application. To analyze the effect, the composite indicators were analyzed using mean and standard deviation. The mean, standard deviation and sample size of respondents to each aspect of each indicator are shown on Table 4.7 below:

Table 4.7: Mean and Standard Deviation of Legal frameworks

\begin{tabular}{|c|c|c|c|}
\hline Legal frameworks & $\mathrm{n}$ & $\begin{array}{c}\text { Mean } \\
(\mathrm{M})\end{array}$ & $\begin{array}{c}\text { Standard } \\
\text { Deviation }\end{array}$ \\
\hline Existence of International Laws & 100 & 3.43 & 1.26 \\
\hline Compliance of National Legislation & 104 & 2.74 & 1.34 \\
\hline Enforcement of county legislations & 104 & 2.96 & 1.26 \\
\hline $\begin{array}{c}\text { Inclusivity of Non-State Actors } \\
\text { Legislations }\end{array}$ & 97 & 3.10 & 1.28 \\
\hline Composite mean & & $\mathbf{3 . 0 5}$ & \\
\hline
\end{tabular}

In terms of ranking, existence of international laws had the highest weight, with a mean of 3.43 , followed by inclusivity of non-state actors' legislations with a mean of 3.10, then enforcement of county legislations with a mean of 2.96 and finally compliance of national legislation with a mean of 2.74. All the mean responses were approximately 3 an indicator that respondents were neutral on the aspect of legal framework being important to performance.

Other key national legislations apart from the aforementioned that promote opportunities for people with disabilities have been drafted, these consist of; the draft equity bill 2000, which aims to combat discrimination faced by various groups, including people with disabilities (GoK 2012). The bill also prohibits employers from paying employees differently for work of equal value. The draft affirmative action bill 2000, which guarantees minority groups, including disabled people, a minimum of 33 per cent of representation in Parliament and on local authorities. According to NCPWD (2003) the draft national disability policy operationalizes the persons with disabilities Act 2003 by providing guidelines for the performance of the Act as equally the draft on special needs education policy, provides a roadmap for the education of children with disabilities. 


\section{International Journal of Science and Research (IJSR) \\ ISSN: 2319-7064}

ResearchGate Impact Factor (2018): 0.28 | SJIF (2019): 7.583

4.3 Correlation between Normative action, Legal frameworks and performance of biosocial projects in informal settlement schemes

In order to establish the direction and magnitude of the relationship between each of the independent variables with the dependent variable, a correlation analysis was done. The results of the correlation are shown on table 4.8 below:

Table 4.8: Correlations among variables

\begin{tabular}{|c|c|c|c|c|}
\hline & & $\begin{array}{c}\text { Performance } \\
\text { of projects }\end{array}$ & \begin{tabular}{|c|} 
Legal \\
framework
\end{tabular} & $\begin{array}{c}\text { Normative } \\
\text { action }\end{array}$ \\
\hline \multirow{3}{*}{$\begin{array}{l}\text { Performance } \\
\text { of projects }\end{array}$} & Correlation & 1 & $.382 * *$ & $.566 * *$ \\
\hline & \multicolumn{2}{|c|}{ Sig. (2-tailed) } & 0.000 & 0.000 \\
\hline & $\mathbf{N}$ & 106 & 91 & 88 \\
\hline \multirow{3}{*}{$\begin{array}{c}\text { Legal } \\
\text { frameworks }\end{array}$} & Correlation & $0.382 * *$ & 1 & $0.751 * *$ \\
\hline & Sig. (2-tailed) & 0.000 & & 0.000 \\
\hline & \begin{tabular}{|c|}
$\mathbf{N}$ \\
\end{tabular} & 91 & 102 & 84 \\
\hline \multirow{3}{*}{$\begin{array}{l}\text { Normative } \\
\text { action }\end{array}$} & Correlation & $0.566 * *$ & $0.751 * *$ & 1 \\
\hline & Sig. (2-tailed) & 0.000 & 0.000 & \\
\hline & $\mathbf{N}$ & 88 & 84 & 97 \\
\hline
\end{tabular}

The results above show that, the independent variable with the strongest correlation with performance of projects was normative action which had a correlation magnitude of 0.566 . The magnitude implied there was a positive moderate correlation between normative action and performance of projects. Legal framework had a weak but positive correlation with performance of projects. Importantly about all the correlation was that they were all statistically significant.

The analysis took to investigate the correlation between the particular indicators of the independent variables and performance. Legal framework was a composite of four elements: Existence of international laws, Compliance of national legislations, Enforcement of county legislations and Inclusivity of Non-state actor's legislations.
The results of the correlation are presented on Table 4.9 below:

Table 4.9: Correlation between legal frameworks and performance of biosocial projects in informal settlements

\begin{tabular}{|c|c|c|c|c|c|}
\hline & $\begin{array}{c}\text { Existence } \\
\text { of } \\
\text { Internatio } \\
\text { nal laws }\end{array}$ & $\begin{array}{c}\text { Complia } \\
\text { nce of } \\
\text { National } \\
\text { Legislati } \\
\text { ons }\end{array}$ & \begin{tabular}{|c|} 
Enforcem \\
ent of \\
County \\
Legislatio \\
ns \\
\end{tabular} & \begin{tabular}{|c|} 
Inclusivit \\
y of \\
Non- \\
State \\
Actors \\
Legislati \\
ons \\
\end{tabular} \\
\hline \multirow{3}{*}{$\begin{array}{c}\text { Performa } \\
\text { nce of } \\
\text { biosocial } \\
\text { projects } \\
\text { in } \\
\text { informal } \\
\text { settlemen } \\
\text { ts }\end{array}$} & $\begin{array}{l}\text { Pearson } \\
\text { Correlati } \\
\text { on }\end{array}$ & $.284^{* *}$ & $.416^{* *}$ & $.361^{* *}$ & $.397^{* *}$ \\
\hline & $\begin{array}{l}\text { Significa } \\
\text { nce level } \\
\text { (2-tailed) }\end{array}$ & .004 & .000 & .000 & .000 \\
\hline & $\mathrm{N}$ & 100 & 104 & 104 & 97 \\
\hline
\end{tabular}

The results show that all the indicators of legal framework are significantly positively correlated with performance of biosocial projects in informal settlements. In terms of the magnitude compliance of national legislations is the highest with $\mathrm{r}=0.416$, followed by inclusivity of Non-state actors legislations with $\mathrm{r}=0.397$, then enforcement of county legislations with $\mathrm{r}=0.361$ and finally existence of international laws with $r=0.284$. Notably all the correlations were moderate.

The indicators for normative action were; social influenceconformity to social norms, social influence-obedience to social norms, social influence-compliance to social norms, cultural beliefs, psychological factors and social empowerment.

Table 4.10: Correlation between Normative action and performance of biosocial projects in informal settlements

\begin{tabular}{|c|c|c|c|c|c|c|c|}
\hline \multicolumn{2}{|c|}{} & $\begin{array}{c}\text { Social influence- } \\
\text { Conformity to } \\
\text { social norms }\end{array}$ & $\begin{array}{c}\text { Social influence- } \\
\text { Obedience to } \\
\text { social norms }\end{array}$ & $\begin{array}{c}\text { Social influence- } \\
\text { Compliance to } \\
\text { social norms }\end{array}$ & $\begin{array}{c}\text { Cultural } \\
\text { beliefs }\end{array}$ & $\begin{array}{c}\text { Psychological } \\
\text { factors }\end{array}$ & $\begin{array}{c}\text { Social } \\
\text { empowerment }\end{array}$ \\
\hline $\begin{array}{c}\text { Performance of } \\
\text { biosocial projects } \\
\text { in informal } \\
\text { settlements }\end{array}$ & Pearson Correlation & $.487^{* * *}$ & $.523^{* *}$ & $.494^{* *}$ & .090 & .144 & $.449^{* * *}$ \\
\cline { 2 - 9 } & Significance level (2-tailed) & .000 & .000 & .000 & .381 & .147 & .000 \\
\hline
\end{tabular}

The results of the correlation between the indicators of normative action and performance are presented on Table 4.10 above:

Results on Table 4.10 above show that apart from cultural beliefs and psychological factors, all the other factors had a positive and moderate correlation with performance of biosocial projects in informal settlements. The magnitude of all the elements which were statistically significant was approximately 0.5 for four of them, indicating a strong correlation. In terms of ranking, the highest was Social influence-Obedience to social norms with $\mathrm{r}=0.523$, followed by Social influence-Compliance to social norms with an $r=0.494$, then Social influence-Conformity to social norms with $r=0.487$ then finally Social empowerment with $\mathrm{r}=0.449$. Cultural beliefs and Psychological factors were not statistically significant as they were below 0.2 indicating weak correlation.

\subsection{Inferential Analysis of Influence of Legal frameworks on Performance of biosocial projects in informal settlements in Nairobi County Kenya}

In order to establish causality between the independent variables and the dependent variable a regression model was run using the Ordinary Least Square method. The regression was conducted to determine whether there is a statistical relationship between the indicators of each independent 


\section{International Journal of Science and Research (IJSR) \\ ISSN: 2319-7064}

ResearchGate Impact Factor (2018): 0.28 | SJIF (2019): 7.583

variable and performance of biosocial projects in informal settlements. The analysis of this relationship coincides with testing of the hypothesis.

On qualitative data, interview guides were administered to sixty one key informants who were state and Non-state actor's stakeholders working with biosocial projects. Purposeful sampling procedure was employed with intent to reach deliberately to the state and non-state actors supporting biosocial community in Nairobi County. Themes under the interview guide were: Effect of social influence by stakeholders during performance of biosocial projects in the informal settlement schemes, conditions that limit PLWD execute their mandates at the household level and also during performance of biosocial projects in informal settlement schemes, how local leaders influence the day to day running of PLWD projects, how performance of projects fair within the informal settlement schemes given the myriad of issues surrounding the biosocial community and understanding of how legal frameworks, normative action and informal settlement schemes affect performance of biosocial projects.

The results were discussed as per the study hypothesis as follows:

\subsubsection{Hypothesis 1}

The objective of the study was to find out the extent to which normative action mediates the relationship between legal frameworks and performance of biosocial projects in informal settlements in Nairobi County. In order to find out this relationship, two steps were followed, step one involved running a regression where legal framework is the only independent variable and then observing the adjusted $\mathrm{R}$ squared coefficient. The second step involved running a multiple regression model which encompasses both normative action and Legal frameworks as the explanatory variables for performance of biosocial projects in informal settlements in Nairobi County.

Ho: The relationship between legal frameworks and performance of biosocial projects in informal settlements in Nairobi County is not mediated by normative action.

\section{Regression model}

The mathematical model that was used to test the null hypothesis was as follows:

Performance of biosocial projects in informal settlements $=f$ (legal frameworks, normative action)

$\mathrm{Y}=\mathrm{f}\left(\mathrm{X}_{1}, \mathrm{X}_{2}, \boldsymbol{\varepsilon}\right)$

$\mathrm{Y}=\beta_{\mathrm{o}}+\beta_{1} \mathrm{X}_{1}+\beta_{2} \mathrm{X}_{2+} \boldsymbol{\varepsilon}$

Where

$\mathrm{Y}=$ Performance of biosocial projects in informal settlements

$\mathrm{X}_{1}=$ Legal Frameworks

$\mathrm{X}_{2}=$ Normative Action

$\beta_{\mathrm{o}}=$ Constant term

$\beta_{1}, \beta_{2}=$ Beta Coefficient

$\boldsymbol{\varepsilon}=$ Error term

Step one: Legal frameworks and Performance of biosocial projects in informal settlements
In the first step, the dependent variable was performance of biosocial projects in informal settlements while the independent variable was legal frameworks for people living with disabilities. The results of step one of the regression model is presented in Table 4.11 below:

Table 4.11: Legal frameworks and Performance of biosocial projects in informal settlements

\begin{tabular}{|l|c|c|c|c|}
\hline \multicolumn{5}{|c|}{ Model Summary } \\
\hline Model & $\mathrm{R}$ & R square & Adjusted R Square & $\begin{array}{l}\text { Std. Error of } \\
\text { the Estimate }\end{array}$ \\
\hline & $382^{\mathrm{a}}$ & 0.146 & 0.136 & 9.819 \\
\hline $\begin{array}{l}\text { a. Predictors: (Constant) Legal frameworks for } \\
\text { People living with Disabilities }\end{array}$ \\
\hline
\end{tabular}

\begin{tabular}{|c|c|c|c|c|c|}
\hline \multicolumn{7}{|c|}{ ANOVA } \\
\hline Model & Sum of squares & Df & Mean Square & F & \\
\hline Regression & 1466.044 & 1 & 1466.044 & & \\
\cline { 1 - 4 } Residual & 8580.11 & 89 & 96.406 & 15.207 & $.000^{\mathrm{b}}$ \\
\hline Total & 10046.154 & 90 & & & \\
\hline
\end{tabular}

a. Dependent Variable: Performance of biosocial projects in informal settlements

b. Predictors: (Constant) Legal frameworks for People living with Disabilities

\begin{tabular}{|c|c|c|c|c|c|}
\hline \multicolumn{7}{|c|}{ Coefficients } \\
\hline \multirow{3}{*}{ Model } & $\begin{array}{c}\text { Unstandardized } \\
\text { Coefficients }\end{array}$ & $\begin{array}{c}\text { Standardized } \\
\text { Coefficients }\end{array}$ & \multirow{2}{*}{$\mathrm{t}$} & \multirow{2}{*}{ Sig. } \\
\cline { 2 - 6 } & $\mathrm{B}$ & $\begin{array}{c}\text { Std. } \\
\text { Error }\end{array}$ & Beta & & \\
\hline (Constant) & 75.256 & 4.224 & & 17.817 & 0 \\
\hline Legal frameworks & 0.218 & 0.056 & 0.382 & 3.9 & 0 \\
\hline
\end{tabular}

Dependent Variable: Performance of biosocial projects in informal settlements

In this analysis the key point to check and consider is on observing the adjusted $\mathrm{R}$ squared of 0.136 when we run step two below.

\section{Step two: Legal frameworks, Normative action and} Performance of biosocial projects in informal settlements In this second step, the mediator variable, normative action, was introduced in the model between legal framework and performance of biosocial projects in informal settlement.

The results of the regression model are seen on Table 4.12 below:

Table 4.12: Normative action, Legal frameworks and Performance of biosocial projects in informal settlements

\begin{tabular}{|c|c|c|c|c|}
\hline \multicolumn{5}{|c|}{ Model Summary } \\
\hline Model & $\mathrm{R}$ & R square & Adjusted R Square & $\begin{array}{c}\text { Std. Error } \\
\text { of the Estimate }\end{array}$ \\
\hline & $.596^{\mathrm{a}}$ & 0.355 & 0.337 & 8.712 \\
\hline
\end{tabular}

a. Predictors: (Constant) Legal frameworks, Normative action

\begin{tabular}{|c|c|c|c|c|c|}
\hline \multicolumn{7}{|c|}{ ANOVA } \\
\hline Model & Sum of squares & Df & Mean Square & F & \\
\hline Regression & 3086.976 & 2 & 1543.488 & & \\
\hline Residual & 5617.102 & 74 & 75.907 & 20.334 & $.000^{\mathrm{b}}$ \\
\hline Total & 8704.078 & 76 & & & \\
\hline
\end{tabular}

a. Dependent Variable: Performance of biosocial projects in informal settlements

b. Predictors: (Constant) Legal frameworks, Normative action 


\section{International Journal of Science and Research (IJSR) \\ ISSN: 2319-7064}

ResearchGate Impact Factor (2018): 0.28 | SJIF (2019): 7.583

\begin{tabular}{|c|c|c|c|c|c|}
\hline \multicolumn{7}{|c|}{ Coefficients } \\
\hline \multirow{3}{*}{ Model } & $\begin{array}{c}\text { Unstandardized } \\
\text { Coefficients }\end{array}$ & $\begin{array}{c}\text { Standardized } \\
\text { Coefficients }\end{array}$ & \multirow{2}{*}{ Sig. } \\
\cline { 2 - 4 } & $\mathrm{B}$ & Std. Error & Beta & & \\
\hline Constant & 51.098 & 6.368 & & 8.025 & .000 \\
\hline Legal frameworks & .105 & .084 & .180 & 1.255 & .213 \\
\hline Normative action & .430 & .086 & .721 & 5.019 & .000 \\
\hline \multicolumn{7}{|c|}{$\begin{array}{c}\text { Dependent Variable Performance of biosocial } \\
\text { projects in informal settlements }\end{array}$} \\
\hline
\end{tabular}

Comparing the results of step two with those of step one, the adjusted $\mathrm{R}$ squared statistics increase from 0.136 to 0.337 representing an increase of $20.1 \%$. This implies, by introduction of normative action in the model, the explanatory power of Legal frameworks to Performance of biosocial projects in informal settlements increased by $20.1 \%$. The results imply we can reject the null hypothesis and accept the alternate hypotheses by concluding that the relationship between legal frameworks and performance of biosocial projects in informal settlements in Nairobi County is mediated by normative action.

Most researchers have the same opinion that participation of target beneficiaries amidst existing policies and external power matrix led by political power wielders may lead to a decision making that is not in a unitary concept. A number of studies suggested that public participation is more in devolved governments as communities in their own setting promote more attachment and social capital in the local positioning (steinheider et al;2006). Conversely according to Probst (2005), he propounds that participative leadership facilitates conversation thus synthesizing all possible avenues of engagements to the ultimate best suited agreed upon notion. Despite the fact that participative decision making takes time, Metzger et al;2012 suggests that the best style to use in an emergency when an immediate decision is needed is an autocratic style that leaves the sole responsibility of making decision to a leader.

Project performance amidst rules and power influence may call for a leader or project manager to exercise complete control and decision making as the responsibility of members of the organization (Cotton et al., 1988), though Debluin (2007) points out that although it might take a while for the members of the organization to arrive at a point of agreement in any given project performance, but the decision arrived that way are among the best since it involves the ideas and skills of many other people.

Qualitative data generated through key informant interviews on understanding of how legal frameworks, and normative action affect performance of projects in informal settlements from a number of respondents they were of the view that all these elements are important in project performance. Nonetheless majority of the views were that the elements have to work together to succeed well. Some of the views were:

"With the two dimensions in place, they may lead to project success."

"When the two items are properly managed, they can lead to project sustainability and consequently a success."
"All parties need to cooperate fully to ensure positive outcome."

Though augmenting the factors was observed to be important, it was nonetheless observed that people did fully understand their legal rights, nor the constitution. Some of the sentiments were:

"Most community members of PLWD don't understand these legal issues and the roles of political leaders on issues of PLWD" "Most of the PLWD don't know and understand their constitutional rights."

"Legal framework: ignorance where people are not aware of their rights because people don't understand them."

"Normative action: some people may question why you are implementing the projects and why their views are not incorporated."

The findings implies that legal legislations enacted within the government if there is no political good will it can only remain pipe dream when it comes to implementation at the projects level.

\section{Conclusion and Recommendations}

This section discusses the summary of the findings based on the objective and hypothesis that was being tested. The findings are mainly based on the F statistic which helps to determine if there is a significant relationship between the response variable and the predictive variable. The $\mathrm{F}$ statistic was judged based on the p-value. In the event the $p$ value was less than 0.05 , it was an implication that the F statistic was statistically significant a further implication that the independent variable statistically explained the dependent variable.

The final objective of the study was to determine the extent to which normative action mediates the relationship between legal frameworks and performance of biosocial projects in informal settlements in Nairobi County, Kenya. The null hypothesis tested was; the relationship between legal frameworks and performance of biosocial projects in informal settlements in Nairobi County is not mediated by normative action. The analysis was done in two steps, the first step was regressing legal framework and performance alone then in the second step running the multiple regression by introducing the mediating factor normative action. The results from the first step were $\mathrm{F}=15.207, \mathrm{p}=0.000<0.05, \mathrm{r}$ $=0.382$, Adjusted $R^{2}=0.136$.

Subsequently, On introduction of normative action to the model, there were various changes, particularly, the correlation coefficient increased from 0.382 being moderate to 0.596 being strong indication a strong correlation, the Adjusted $\mathrm{R}^{2}$ increased from 0.136 to 0.337 , which was an increase of $20.01 \%$. The increase in the adjusted $R^{2}$ coefficient was quite large implying normative action strongly mediated the influence of legal framework on performance of projects. The increase in the $F$ statistic as well affirmed the mediating effect; particularly normative action boosted the influence of legal framework on

Volume 9 Issue 6, June 2020 www.ijsr.net 


\section{International Journal of Science and Research (IJSR) \\ ISSN: 2319-7064}

ResearchGate Impact Factor (2018): 0.28 | SJIF (2019): 7.583

performance of biosocial projects in informal settlements in Nairobi County thus leading to rejection of null hypothesis.
Table 5.1 below present summary of tests of Hypotheses and results

Table 5.3: Summary of Tests of Hypotheses and Results

\begin{tabular}{|c|c|c|c|c|}
\hline Research Objective & Hypotheses & Results & Table & Remarks \\
\hline $\begin{array}{l}\text { To determine the extent to } \\
\text { which normative action } \\
\text { mediates relationship between } \\
\text { legal frameworks and } \\
\text { performance of biosocial } \\
\text { projects in informal settlements } \\
\text { in Nairobi County, Kenya. }\end{array}$ & $\begin{array}{c}\text { Ho: The relationship } \\
\text { between legal frameworks } \\
\text { and performance of biosocial } \\
\text { projects in informal } \\
\text { settlements in Nairobi } \\
\text { County is not mediated by } \\
\text { normative action. }\end{array}$ & $\begin{array}{l}\text { Step 1: } \\
\mathrm{F}=15.207 \\
\mathrm{p}=0.000<0.05 \\
\mathrm{r}=0.382 \\
\text { Adjusted } \mathrm{R}^{2}=0.136 \\
\text { Step 2: } \\
\mathrm{F}=20.334 \\
\mathrm{p}=0.000<0.05 \\
\mathrm{r}=0.596 \\
\text { Adjusted } \mathrm{R}^{2}=0.337\end{array}$ & $\begin{array}{c}\text { Table } 4.11 \\
\text { and Table } \\
4.12\end{array}$ & $\begin{array}{l}\text { Rejected the null hypotheses. } \\
\mathrm{R}^{2} \text { increased by } 20.1 \% \text { and } \mathrm{F} \\
\text { statistics increased too the effect } \\
\text { of relationship of legal } \\
\text { frameworks on performance of } \\
\text { biosocial projects }\end{array}$ \\
\hline
\end{tabular}

Conclusively, the objective of this study was concerned with the mediating effect of normative action on the influence of legal framework on performance of projects. The results showed that normative action had a very positive mediating effect on legal framework. Particularly, it increased the influence of legal framework on performance of biosocial projects in Nairobi County thus leading to the rejection of null hypothesis.

The study observed and recommends that there is a need on ensuring people living with disabilities are actively involved in decision making as well as ensuring staff are skilled and stakeholders have no vested interest to avoid diversion of funds to other things thus collapsing the biosocial projects. However, the state should formulate and implement national policies, programs and legislation to provide equal participation of persons with disabilities, as what they champion is not having special privileges but having an equal and level playing field that is premised on equity but not equality. Conversly, this study recommends that there is need to study further legal framework that insulates biosocial community from political manipulations.

\section{References}

[1] Alan Bryman. (2001). Social Research Methods. Oxford University Press

[2] Ahlemann, F., El Arbi, F., Kaiser, M. G., \& Heck, A. (2012). A process framework for theoretically grounded prescriptive research in the project management field. International Journal of Project Management, 3 (1), 456.

[3] Corder, G. W.; Foreman, D. I. (2009). Nonparametric Statistics for Non-Statisticians: A Step-by-Step Approach. Wiley. ISBN 978-0-470-45461-9.

[4] Cloninger CR (1985). "A unified biosocial theory of personality and its role in the

[5] Creswell, J.W. (2012). Educational research: Planning, conducting, and evaluating Quantitative and qualitative research. Upper Saddle River, NJ: Prentice Hall.

[6] Crandall CS, Eshleman A, O’Brien L(2002): Social norms and the expression and suppression of prejudice: the struggle for internalization. J Pers Soc Psychol 2002, 82:359-378.

[7] Gakuu, Kidombo and Keiyoro (2016).Fundamentals of Research methods: Concepts, Practiv and Application. Kenya Aura Publishers.
[8] Government of Kenya. (2002). National Development Plan 2002 - 2008. Ministry of Planning. Government Printer, Nairobi.

[9] Lantz Bjorn. (2013). Equidistance of Likert-Type Scales and Validation of Inferential Methods Using Experiments and Simulations. The Electronic Journal of Business Research Methods Volume 11 Issue 12013 (pp 16-28), ISSN 1477-7029 16 @ACPIL

[10]Linehan, Marsha, 2014. M. DBT® skills training manual. Guilford Publications.

[11]Linehan, Marsha, 2014. DBT® Skills Training Handouts and Worksheets. Guilford Publications.

[12] Moriya, N. (2008). Noise-Related Multivariate Optimal Joint-Analysis in Longitudinal Stochastic Processes in Progress in applied mathematical modeling". In Fengshan Yang. Progress in 224 Applied Mathematical Modeling. Nova Science Publishers, Inc. pp. 223-260. ISBN 978-1-60021-976-4.

[13] Mugenda M Olive, (2008). Research Methods: Qualitative and Quantitative, Nairobi Acts Press.

[14] Nairobi County Integrated Development plan, NCIDP 2013-2014

[15]Nyonje, Kyalo and Mulwa (2012).Monitoring and Evaluation of Development projects and programmes. Kenya Aura Publishers.

[16] SaundersM., LewisP., ThornhillA.(2003).ResearchMethodsforBusinessStudent $s$. PrenticeHallPublishers3rdEdition.

[17] Shapiro, S. S.; Wilk, M. B. (1965). An analysis of variance test for normality (complete samples). Bimetrika 52 (3-4): 591-611

[18] Shield, Patricia and Rangarjan, N. (2013). A Playbook for Research Methods: Integrating Conceptual Frameworks and Project Management. Stillwater, OK: New Forums Press.

[19] World Bank. 2003. Adolescents and Youth with Disability: Issues and Challenges. International Policy and Program Review with Recommendations. Washington, DC: World Bank. Accessed March 2014. http://siteresources.worldbank.org/EXTLACREGTOPH IVAIDS/Resources/Adolescents and Disability Final.pdf WHO/World Bank. 2011. World Report on Disability. Geneva: WHO. Accessed March 9, 2014. http://www.who.int/disabilities/world_report/2011/en/

[20] Van Zomeren, M. (2013). Four core socialpsychological motivations to undertake Collective 


\section{International Journal of Science and Research (IJSR) \\ ISSN: 2319-7064}

ResearchGate Impact Factor (2018): 0.28 | SJIF (2019): 7.583

action. Social and Personality Psychology Compass, 7, 378-388.

[21] Van Zomeren, M., Postmes, T., Spears, R., \& Bettache, K. (2011). Can moral convictions Motivate the advantaged to challenge social inequality? Extending the social identity Model of collective action. Group Processes and Intergroup Relations, 14, 735-754.

Volume 9 Issue 6, June 2020 www.ijsr.net 